(RESEARCH ARTICLE)

\title{
Gas chromatography / mass spectrometry (GC-MS) analysis of Jatropha curcas latex and its antimicrobial activity on clinical isolates
}

\author{
Obafemi Adetayo Solesi 1, 2, ${ }^{*}$, Felicia Chinomnazu Adesina ${ }^{1}$, Bukola Christianah Adebayo-Tayo ${ }^{3}$ and \\ Abiodun Sunday Abiodun 4 \\ ${ }^{1}$ Department of Microbiology, Lead City University, Ibadan, Nigeria. \\ 2 Department of Pharmacy Technician Programme, Ogun State College of Health Technology, Ilese-Ijebu, Nigeria. \\ ${ }^{3}$ Department of Microbiology, University of Ibadan, Ibadan, Nigeria. \\ ${ }^{4}$ Department of Environmental Health and Diseases Control, Ogun State College of Health Technology, Ilese-Ijebu, \\ Nigeria.
}

Publication history: Received on 04 September 2020; revised on 27 September 2020; accepted on 29 September 2020

Article DOI: https://doi.org/10.30574/wjarr.2020.8.1.0340

\begin{abstract}
The increasing rate of resistance to antibiotics has led to endless search for new drugs of natural origin with antimicrobial activities. The work was aimed at evaluating the phyto-constituents of $J$. curcas latex and its antibacterial activities against some selected clinical bacterial isolates. Gas chromatography / mass spectrometry (Gc-ms) analysis of latex of J. curcas phyto-constituents was done and tested for antibacterial activity. Antibacterial activity of the latex was determined on some selected clinical bacterial isolates using cup plate agar diffusion bioassay method. The main constituents include:-alpha.-benzamido-2-hydroxycinnamic acid, Pentanoic acid, 3-methyl-, N,Ndimethylaminoethanol, (2E,4E)-N-isobutyltetradeca-2,4-dienamide, Oxime-, methoxy-phenyl-, 1-(4-methoxy-3methylphenyl)-2-methylpropan-2-amine, Maltol-dodecanoic acid, methyl ester, Theobromine, Hexadecanoic acid, Methyl ester, Methyl stearate, 1,1,2-trimethyl-3,8,9-trioxa-bicyclo[4.2.1]nonane. Antibacterial activity of latex on clinical isolates of Escherichia coli, Bacillus spp, Klebsiella pneumonia, Pseudomonas aeruginosa, Staphylococcus aureus, Citrobacter spp and Salmonella typhi showed the latex had relatively high activity against all these bacteria except Citrobacter spp and Salmonella typhi. Latex of J. curcas had considerable percentage of therapeutically useful phytoconstituents and activity against most clinical bacteria isolates used in this work.
\end{abstract}

Keywords: Jatropha; Phyto-constituents; Gas-chromatography; Antibacterial activity; K. pneumonia; P. aeruginosa.

\section{Introduction}

The increasing rate of resistance to antibiotics has led to endless search for new drugs of natural origin with antimicrobial activities. Plants and their secondary metabolites (alkaloids, terpenoids and phenolic compounds) are prospective antimicrobial agents that can be useful in eliminating the crisis of antibiotic resistance [1].

Medicinal plants have immensely supported human health as being utilized as explorative compounds of drugs [2], for treatment of different ailments. The majority of rural populace of Nigeria and other parts of Africa have been using medical plants in the primary health care [3]. The World Health Organization [4] reported that more than 80\% of the world's population especially developing nations depend on medicinal plants as means of medicines for primary healthcare.

\footnotetext{
*Corresponding author: Obafemi Adetayo Solesi

Department of Microbiology, Lead City University, Ibadan, Nigeria.
} 
Jatropha curcas belongs to the family Euphorbiaceae and is mostly cultivated for large scale biodiesel production from its seed $[5,6]$. It is employed in traditional medicine for the treatment of many ailments in subtropical and semi-arid regions [2]. Some parts of the plant; the seed, leaf and latex have many uses in treating infectious diseases [7]. The latex is used in treating wound and as blood anticoagulant [8], the leaf has insecticidal and antimicrobial activity $[9,10]$.

\subsection{Statement of Problem}

The increasing rate of resistance to antibiotics has led to endless search for new drugs of natural origin with antimicrobial activities [1].

\subsection{Aim}

Gas Chromatography-mass spectroscopy phyto-constituents analysis and antibacterial activities of Jatropha curcas latex.

\subsection{Objectives}

- To determine the phytochemical properties of Jatropha curcas latex

- To determine the antimicrobial activities of the latex against some selected pathogens.

\section{Methodology}

\subsection{Collection of samples}

Fresh crude latex was aseptically obtained from the stem of Jatropha curcas by incision using sterile surgical knife and collected into sterile sample bottles. The milky latex was stored air tight in the refrigerator at $4{ }^{\circ} \mathrm{C}$ and kept for further experiment.

\subsection{Collection of test organisms}

Seven bacterial isolates from clinical sources: Escherichia coli, Bacillus spp., Klebsiella pneumonia, Pseudomonas aeruginosa, Staphylococcus aureus, Citrobacter spp. and Salmonella typhi were collected from the department of medical microbiology laboratory, University College Hospital (UCH), Ibadan. The isolates were then sub-cultured on plates of nutrient agar and incubated for 24 hours at $37+2{ }^{\circ} \mathrm{C}$. Culture obtained for each bacterium was used for further work while stock cultures were also made from this.

\subsection{Gas chromatography- mass spectrometry analysis (Gc-ms) of latex samples}

The compounds in the latex of Jathropha curcas were quantitatively measured by Gc-ms based on the method described by [11] with some modification. The Gc-ms system used was a Schimadzu QP2010PLUS system. Six microliters were analyzed on a BPX-5 SGE ultra-low bleed 5\% phenyl polydimethylsiloxane capillary column $(30 \mathrm{~m} \times 0.25 \mathrm{~mm}$ i.d. $\times 0.25$ $\mu \mathrm{m}$ film thickness). Split less injection was performed with a purge time of 1.0 minutes. The carrier gas was Helium at a flow rate of $1 \mathrm{ml} \mathrm{min}-1$. The column temperature was maintained at $50{ }^{\circ} \mathrm{C}$ for $3 \mathrm{~min}$, then programmed at $5{ }^{\circ} \mathrm{C}$ min- 1 to $80^{\circ} \mathrm{C}$ and then at $10^{\circ} \mathrm{C}$ min- 1 to $340^{\circ} \mathrm{C}$. The inlet and detector temperatures were $250{ }^{\circ} \mathrm{C}$ and $340{ }^{\circ} \mathrm{C}$, respectively, and the solvent delay was 4 minutes.

The identification of the peaks was based on computer matching of the mass spectra with the National Institute of Standards and Technology (NIST 14.L) library and by direct comparison with published data.

\subsection{Sensitivity test using agar well diffusion method}

Plates of sterile nutrient agar were prepared and the test organisms stored in slants were aseptically picked with sterile inoculating loop and sub-cultured on the nutrient agar plates by spread plate method and incubated for 24 hours at 37 ${ }^{\circ} \mathrm{C}$. A colony of each isolate was aseptically re-inoculated into McCartney bottles containing $10 \mathrm{mls}$ of sterile water. Following the MacFarland standard of 0.5[12], a sterile swab stick was placed in each suspension and used in spreading each pathogenic isolate on plates of Mueller Hinton Agar (MHA) for sensitivity tests using the Agar Well Diffusion method [13]. A sterile $8 \mathrm{~mm}$ cork- borer, was used in boring wells on the agar and a micropipette was used in dispensing $100 \mu \mathrm{L}$ of the latex into labeled wells, $60 \mu \mathrm{L}$ of standard Streptomycin was used as positive control [14]. 


\section{Results and discussion}

\subsection{Phyto-constituents of Jatropha curcas latex}

Gas Chromatography-Mass Spectrometer analysis of Jatropha curcas latex showed the presence of 31 components, with twelve major phytochemicals (Table 1), the typical total ion chromatograms (TIC) is displayed in Figure 1.

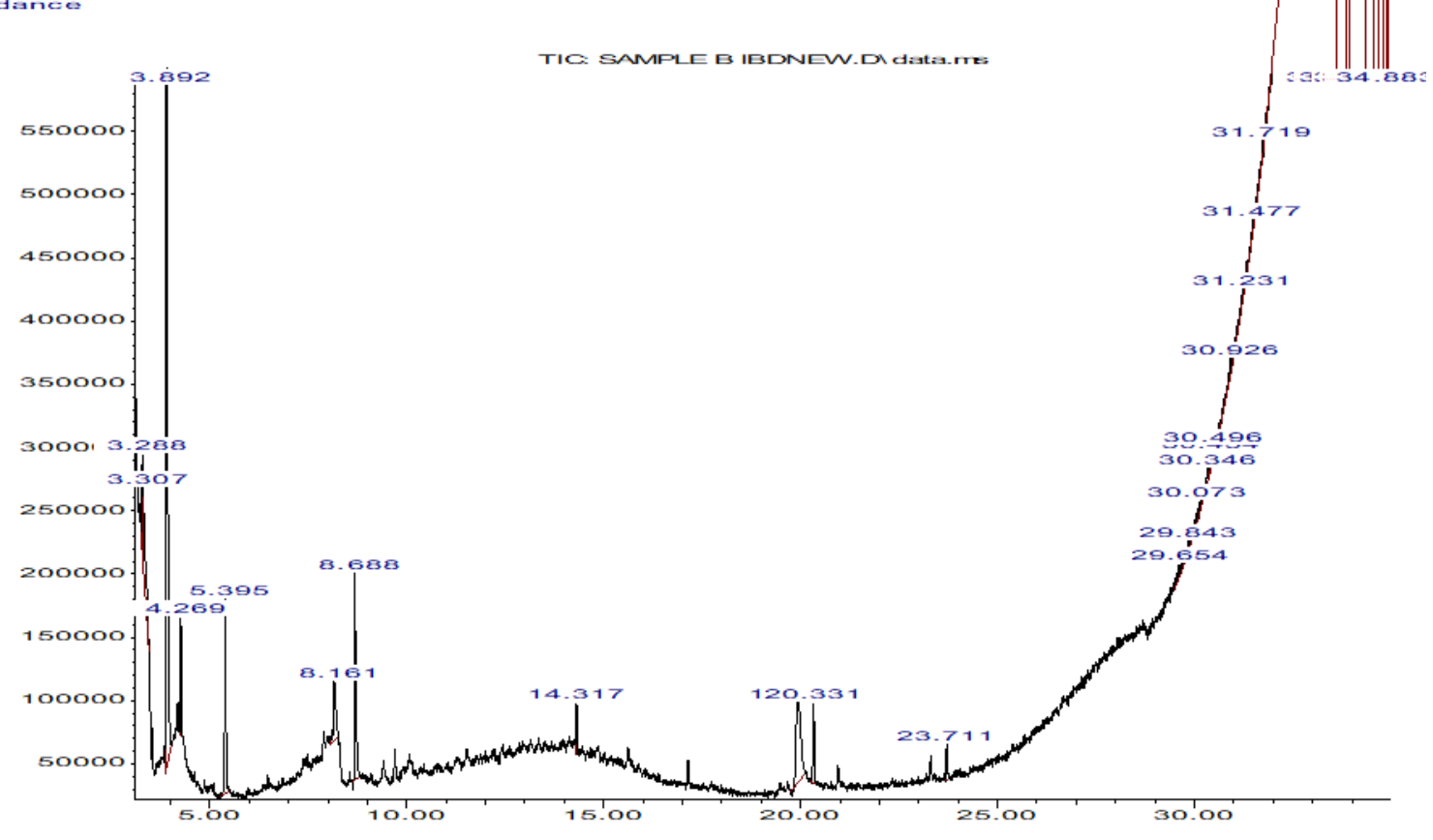

Figure 1 Showing typical GC-MS Total ionic chromatogram (TIC) of hexane/methane (1:1) Jatropha curcas latex.

Table 1 The major phyto-constituents of extract of Jatropha curcas latex

\begin{tabular}{|c|c|c|c|c|c|c|}
\hline SN & $\begin{array}{l}\text { PHYTOCHEMICAL } \\
\text { NAME }\end{array}$ & M.M & F.M & Chemical structure & $\begin{array}{l}\text { Chemical } \\
\text { nature }\end{array}$ & $\begin{array}{l}\text { Biological } \\
\text { Activity }^{* *}\end{array}$ \\
\hline 1 & $\begin{array}{l}\text { alpha.-Benzamido-2- } \\
\text { hydroxycinnamic acid }\end{array}$ & 283 & $\mathrm{C}_{16} \mathrm{H}_{13} \mathrm{NO}_{4}$ & $\sum_{0}$ & Phenolic acids & $\begin{array}{l}\text { Flavors, } \\
\text { antioxidant,a } \\
\text { nti- } \\
\text { inflammatory, }\end{array}$ \\
\hline 2 & $\begin{array}{l}\text { Pentanoic acid, 3- } \\
\text { methyl- }\end{array}$ & 116 & $\mathrm{C}_{6} \mathrm{H}_{12} \mathrm{O}$ & & Fatty Acids & $\begin{array}{l}\text { Flavor, } \\
\text { Antispasmodi } \\
\text { c, } \\
\text { Hypotensive, } \\
\text { Sedative }\end{array}$ \\
\hline 3 & $\begin{array}{l}\mathrm{N}, \mathrm{N}- \\
\text { Dimethylaminoethan }\end{array}$ & 89 & $\mathrm{C}_{4} \mathrm{H}_{11} \mathrm{NO}$ & & $\begin{array}{l}\text { Tertiary amine } \\
\text { with Hydroxy } \\
\text { group }\end{array}$ & $\begin{array}{l}\text { Improve Skin } \\
\text { Health and } \\
\text { Cognitive } \\
\text { Function }\end{array}$ \\
\hline
\end{tabular}

$4 \quad(2 \mathrm{E}, 4 \mathrm{E})-\mathrm{N}-$

$279 \quad \mathrm{C}_{18} \mathrm{H}_{33} \mathrm{NO}$

Alkaloid

Antimycobact e-ria,

Isobutyltetradeca-

2,4-dienamide 
Oxime-, methoxy- $151 \quad \mathrm{C}_{8} \mathrm{H}_{9} \mathrm{NO}_{2}$

phenyl-

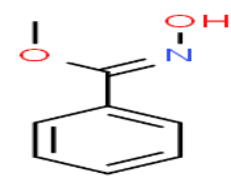

Antimicrobial

and

Antioxidant

6 1-(4-Methoxy-3-

$193 \quad \mathrm{C}_{12} \mathrm{H}_{19} \mathrm{NO}$

Unknown

Activity

methylphenyl)-2-

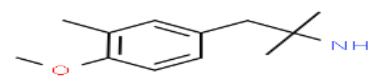

methylpropan-2-

amine

$7 \quad$ Maltol

$126 \quad \mathrm{C}_{6} \mathrm{H}_{6} \mathrm{O}_{3}$

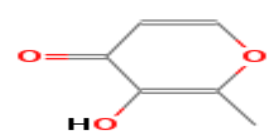

unsaturated cyclic cmpd

Dodecanoic acid, $214 \quad \mathrm{C}_{13} \mathrm{H}_{26} \mathrm{O}_{2}$

methyl ester



Lauric acid, Antibacterial, methyl Antiviral, ester(Fatty Hypercholest Acid Methyl er-olemic, ester) Candidicide.

9 Theobromine $\quad 180 \quad \mathrm{C}_{7} \mathrm{H}_{8} \mathrm{~N}_{4} \mathrm{O}_{2}$ (FAME)

(a)

Primary alkaloid

Antiasthmatic , Arteriodilator , Diuretic, Myocardiotonic, Pesticide.

10 Hexadecanoic acid, $270 \quad \mathrm{C}_{17} \mathrm{H}_{34} \mathrm{O}_{2}$ methyl ester

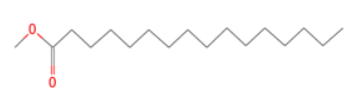

Palmitic acid, Hypercholest methyl er-olemic, ester(FAME) Hemolytic, Flavor, Antioxidant, Antimicrobial

11 Methyl stearate $298 \quad \mathrm{C}_{19} \mathrm{H}_{38} \mathrm{O}_{2}$



Stearic acid, Antimicrobial, methyl ester Antioxidant (FAME) Unknown / Unknown

12 1,1,2-Trimethyl$172 \quad \mathrm{C}_{9} \mathrm{H}_{16} \mathrm{O}_{3}$ 3,8,9-trioxa-bicyclo [4.2.1]nonane probably new chemical compound

**Source: Dr .Duke's phytochemical and Ethnobotanical databases [Online database] [15].M.M=; F.M =. KEY: M.M- Molecular mass, F.M. - formula, S.N. - Serial number.

\subsection{Antimicrobial activity}

The antibacterial potential of the Jatropha curcas latex samples against some selected clinical isolates is shown in Table 2. The antibacterial activity of the latex from Jatropha curcas against some pathogens ranged from 4.0-8.0 $\mathrm{mm}$. The susceptibility of the pathogen is in the ascending order of K. pneumonia which is $>$ E. coli, $\geq P$. aeruginosa $>$ S. aureus $>$ Bacillus spp. while Citrobacter spp. and Salmonella typhi were not susceptible to the latex of Jatropha curcas. 
Table 2 Antibacterial activity of Jatropha curcas latex on some selected clinical isolates

\begin{tabular}{lll}
\hline S/N & Organism & Zone of Inhibition (mm) \\
\hline 1 & Escherichia coli & 6.0 \\
2 & Bacillus spp & 4.0 \\
3 & Klebsiella pneumonia & 8.0 \\
4 & Pseudomonas aeruginosa & 6.0 \\
5 & Staphylococcus aureus & 5.0 \\
6 & Citrobacter spp & - \\
7 & Salmonella typhi & - \\
\hline \multicolumn{2}{c}{ S/N = serial number; mm= millimeter. }
\end{tabular}

\section{Discussion}

The increasing antibiotics resistance as being the major challenge to the scientist lately, and use of natural agents to combat it has also been explored. Hence, this study was one of such, using Jatropha curcas latex as an agent in prospecting for possible new $\operatorname{drug}(\mathrm{s})$.

The results of the phytochemical analysis using Gc-ms showed that Jatropha curcas latex extract of hexane/methane contained twelve major constituents- alpha.-Benzamido-2-hydroxycinnamic acid, Pentanoic acid, 3-methyl-, N,NDimethylaminoethanol, (2E,4E)-N-Isobutyltetradeca-2,4-dienamide, Oxime-, methoxy-phenyl-, 1-(4-Methoxy-3methylphenyl)-2-methylpropan-2-amine, Maltol, Dodecanoic acid, methyl ester, Theobromine, Hexadecanoic acid, methyl ester, Methyl stearate, 1,1,2-Trimethyl-3,8,9-trioxa-bicyclo [4.2.1]nonane. The bioactive components range from being phenolic acids, fatty acids, fatty- acids methyl ester, alkaloid, tertiary amines and flavonoids in nature, which have antimicrobial properties and may confer the antimicrobial effect as shown by the result. Pentanoic acid, 3-methylhexadecanoic acid, methyl-ester are considered as flavonoids [15], and flavonoids have also been reported to have antimicrobial properties $[16,17]$.

The effects of the Jatropha curcaslatex on the test organisms showed variation on the zones of inhibition produced and but more pronounced on Gram-negative than the Gram- positive test organisms. This variation may be due to nature and genetic property of the organism under tested, such as the cell- wall, spore formation and encapsulation which have been reported to aid resistance to microorganism $[18,19]$.

The above results indicated that the Jatropha curcas latex exhibited antimicrobial properties, and justifying scientifically their traditional use as medicinal plant. And further suggested that the latex contain bio-actives which are effective against some strains of bacteria tested as reported by Arekemase [20].

The latex extract was active against Klebsiella pneumonia, Pseudomonas aeruginosa and Staphylococcus aureus. Thus agreed with report of Ekundayo et al. [21]. Some of the common health condition caused by Klebsiella pneumonia and Pseudomonas aeruginosa are pneumonia and complication in surgical wound sites, urinary tract, and lower biliary tract infection [22,23]. The inhibition of $S$. aureus by the latex extract emphasizes the traditional use of the J. curcas in wound healing, scabies and other skin infections [24]

Some of the phytochemicals like Dodecanoic acid, methyl ester, Hexadecanoic acid, methyl ester, Methyl stearate are fatty-acids methyl ester and have been reported to have antimicrobial property [25].

In this study, 1,1,2-Trimethyl-3,8,9-trioxa-bicyclo [4.2.1]nonane and 1-(4-Methoxy-3-methylphenyl)-2-methylpropan2-amine were found to likely be new and/ or unknown substance with unknown biological activity which may have contributory antimicrobial effect on test organisms.

\section{Conclusion}

Jatropha curcas extract had antimicrobial effect on the clinical isolates utilized in this work. The test organisms are of biomedical interest. Future work may include further purification of Jatropha curcas latex and tested on these test organisms for possible drug development against infections caused by these microorganisms. 


\section{Compliance with ethical standards}

\section{Acknowledgments}

The authors appreciated Mr. Alao S. Omoniyi of the department of microbiology, University of Ibadan and his team for the technical support on laboratory work.

\section{Disclosure of conflict of interest}

The authors declare no conflict of interest of any kind on this publication.

\section{References}

[1] Krishnaiah D, Devi T, Bono A, Sarbatly R. Studies on phytochemical constituents of six Malaysian medicinal plants. J. Med. Plants Res. 2009; 3(2): 067-072.

[2] Rampadarath S., Puchooa D, Jeewon R. Jatropha curcas L: Phytochemical, antimicrobial and lavicidal properties. Asian Pacific Journal of Tropical Biomedicine. 2016; 6(10): 858-865.

[3] Ekundayo EO, Ekekwe JN. Antibacterial activity of leaves extract of Jatropha curcasand Euphorbia heterophylla.African Journal of Microbiology Research.2013; 7(4): 5079-5100.

[4] World Health Organization (WHO).Traditional Medicine: Growing Needs and Potential.WHO policy perspective on Medicine. World Health Organization, Geneva. 2002; 1-6.

[5] Tapanes NCO, Aranda DAG, de MesquitaCarneiro JW, Antunes OAC. Transesterification of Jatropha curcas oil glycerides: theoretical and experimental studies of biodiesel reaction. Fuel. 2008; 87: 2286-2295.

[6] Berchmans HJ, Hirata S. Biodiesel production from crude Jatropha curcas L. seed oil with a high content of free fatty acids. Bioresour. Technol. 2008; 99: 1716-1721.

[7] Namuli A, Abdullah N, Sieo CC, Zuhainis SW, Oskoueian E. Phytochemical compounds and antibacterial ctivity of Jatropha curcasLinn.Extracts. Journal of Medicinal Plants Research. 2011; 5(16): 3982-3990.

[8] Osoniyi 0,Onajobi F.Coagulant and anticoagulant activities in Jatropha curcas latex. Journal of Ethnopharmacology. 2003; 89: 101-105.

[9] Kalimuthu K, Vijayakumar S, Senthilkumar R. Antimicrobial activity of the biodiesel plant, Jatropha curcas L. Int. J. Pharm. Biol. Sci. 2003; 1: 1-5.

[10] Chauhan N, Kumar P, Mishra S, Verma S, Malik A, Sharma S. Insecticidal activity of Jatropha curcas extracts against housefly, Musca domestica. Environ. Sci. Pollut. Res. 2015; 22: 14793-14800.

[11] Hossain and Rahman. Chemical Composition of Bioactive Compounds by GC-MS Screening and Anti-fungal Properties of the Crude Extracts of Cabbage Samples. Asian Journal of Biotechnology. 2011; 3: 68-76.

[12] Cockerill, Franklin R. Methods for dilution antimicrobial susceptibility tests for bacteria that grow aerobically: approved standard. Wayne, Pa: Clinical and Laboratory Standards Institute. 2012.

[13] Michael Hombach, Florian P. Maurer, Tamara Pfiffner, Erik C. Böttger, ReinhardFurrer. Standardization of Operator-Dependent Variables Affecting Precision and Accuracy of the Disk Diffusion Method for Antibiotic Susceptibility TestingJournal of Clinical Microbiology. Nov 2015; 53(12): 3864-3869.

[14] Raj Kumar Salar, Pooja Sharma, Naresh kumar. Enhanced antibacterial activity of streptomycin against some human pathogens using green synthesized silver nanoparticles. Elsevier: Resource-efficient Technologies. 2015; 1(2): 106-115.

[15] Duke Jim. Duke's phytochemical and Ethnobotanical databases [Online database].Fulton: National Agricultural Library; 1995[1996; cited 2020 August 17]. (https://phytochem.nal.usda.gov/phytochem/search/list).

[16] Cushnie TP andLamb AJ. Recent advances in understanding the antibacterial properties of flavonoids. International Journal of Antimicrobial Agents. 2016; 38(2): 99-107.

[17] Manner S, Skogman M, Goeres D, Vuorela P, Fallarero A. Systematic exploration of natural and synthetic flavonoids for the inhibition of Staphylococcus aureus biofilms. International Journal of Molecular Sciences. 2013; 14(10): 19434-19451. 
[18] Joynson JA, Forbes B, Lambert RJW.Adaptive resistance to benzalkonium chloride, amikacin and tobramycin: the effect on susceptibility to other antimicrobials. J ApplMicrobiol. 2002; 93: 96-107.

[19] Mostafa AA, Al- Askar AA, Almaary KS, Dawoud TM, Shokamy EN, Bakri MM. Antimicrobial activity of some plants extracts against bacterial strains causing food poisoning disease. Saudi J Bio Sci. 2017Mostafa AA, Al-Askar AA, Almaary KS, Dawoud TM, Sholkamy EN, Bakri MM. Antimicrobial activity of some plant extracts against bacterial strains causing food poisoning diseases. Saudi J Biol Sci. 2018;25(2):361-366.

[20] Arekemase MO, Kayode RMO, Ajiboye AE. Antimicrobial Activity and Phytochemical Analysis of Jatropha curcas Plant against Some Selected Microorganisms. International journal of Biology. 2011; 3(3): 52-59.

[21] Ekundayo FO, Adeboye CA, Ekundayo EA. Antimicrobial screening of pignut (J.curcas Linn.) on some pathogenic bacteria. J.Med.Plant. Res. 2011; 5(7):1261-1264.

[22] Brooks GF, Butel JS, Morse SA, Carroll KC, Mietzner TA. Medical Microbiology, 23rd Ed. New York: McGraw-Hall Companies.2004.

[23] Ryan KJ, Ray CG Sherris. Medical microbiology, 4th Ed.New York. McGraw-Hall Companies. 2004.

[24] Thomas T, Sah NK, Sharma PB. Therapeutical biology of Jatropha curcas: A Mini Review. Curr Pharm Biotechnol. 2008; 9(4): 315-324.

[25] Colin P. Churchward, Raid G. Alany\& Lori A. S. Snyder. Alternative antimicrobials: the properties of fatty acids and monoglycerides, Critical Reviews in Microbiology. 2018; 44(5): 561-570. 